\title{
Self-Efficacy Relationship on Science Achievement amongst National Secondary School Students
}

\author{
Nor Liyana Jamil, Siti Nur Diyana Mahmud* \\ Faculty of Education, Universiti Kebangsaan Malaysia, Bangi, Malaysia \\ Email: ^diyana@ukm.edu.my
}

How to cite this paper: Jamil, N. L., \& Mahmud, S. N. D. (2019). Self-Efficacy Relationship on Science Achievement amongst National Secondary School Students. Creative Education, 10, 2509-2527. https://doi.org/10.4236/ce.2019.1011179

Received: October 31, 2019

Accepted: November 24, 2019

Published: November 27, 2019

Copyright (อ 2019 by author(s) and Scientific Research Publishing Inc. This work is licensed under the Creative Commons Attribution International License (CC BY 4.0).

http://creativecommons.org/licenses/by/4.0/

\section{(c) (i) Open Access}

\begin{abstract}
This study has aimed to identify the relationship of self-efficacy in science with academic achievement amongst national secondary school students in the Rompin district. This study is a quantitative research using the survey method through a questionnaire. A total of 191 students from 4 schools in the Rompin were involved in this study. The data were analysed using descriptive and inferential statistics methods. This study found that practical work was the highest contributing factor to student self-efficacy $(M=3.77, S D=0.572)$ whilst cognitive skills were the lowest contributor $(\mathrm{M}=3.13, \mathrm{SD}=0.437)$. An independent sample t-test analysis showed that there were significant differences in the self-efficacy of science between male and female students. The study found that female students' self-efficacy $(\mathrm{M}=3.49, \mathrm{SD}=0.363)$ was higher than for males $(\mathrm{M}=3.28, \mathrm{SD}=0.384)$. The Pearson correlation test showed that there was no significant relationship between self-efficacy and academic achievement, where $\mathrm{r}=0.124$ and $p=0.09$. The implication of the findings from this study can assist the Ministry of Education Malaysia (MOE), schools, and teachers, especially science education teachers, in developing strategies to enhance student science self-efficacy and thus, increase students' participation in Science streams.
\end{abstract}

\section{Keywords}

Self-Efficacy, Science Self-Efficacy, Academic Achievement

\section{Introduction}

Science and Technology can influence our daily lives in many ways (e.g. health, climate, work) and provide job opportunities; as well, it is pivotal in promoting 
economic growth (Henriksen et al., 2015). According to the US Department of Commerce (2011) in Baker (2013), Science, Technology, Engineering, and Mathematic (STEM) areas have greater job opportunities and salaries than the non-STEM fields. Therefore, maximising the number of students pursuing the STEM fields has become the main objective in initiatives and reformation made by many countries in order to ensure that the students are ready and qualified to participate in STEM careers (McDonald, 2016). However, in recent years, there have been concerns regarding the declining participation and interest in science amongst students (Wilson \& Mack, 2014; Lyons \& Quinn, 2010). Therefore, this declining phenomenon can be a threat to any developing country including Malaysia.

In Malaysia, to achieve the country's goal of producing experts in science and technology, the National Science, Technology, and Innovation Policy has been aiming at implementing science, technology, and innovation practices in every community (MOSTI, 2016). However, community involvement, especially amongst students, in science has not been satisfactory. Yee \& Fah (2014) stated that student participation in science at schools and universities is low. The number of students pursuing the science stream amongst secondary school students in Malaysia is only $29 \%$ and it is far from the goal of the Ministry of Education Malaysia to set a target of $60 \%$ of student participation in Science/Technical and $40 \%$ in the Art stream (Halim \& Meerah, 2016; Nazirah et al., 2013). Based on the Programme for International Student Assessment (PISA) 2015, Malaysia showed an increase in the score for the Science domain which was 443 compared to 420 in the PISA 2012. However, the score did not achieve the average OECD score which was 493. In addition, compared to other developing countries, such as China and Vietnam, science performance amongst Malaysian students is still far behind (Da Wan et al., 2018).

The deterioration of the science achievement amongst students has sparked numerous studies to investigate the causes of the issue. Phang et al. (2014) analysed the contributing factors to bring about a decline in the trend of students' participation in the science stream from 2001-2010 and they found that the contributing factors were attitude, interest, perception, student anxiety, and motivation for science learning. Furthermore, Adnan and Ghazali (2011) stated that, students' motivation for science learning can be influenced by their self-efficacy. According to Abu-Tineh, Khasawneh, and Khalaileh (2011), the level of self-efficacy can influence the attitudes in learning exhibited by students. In Malaysia, several studies on self-efficacy have been conducted in the context of education. Most recent studies have focused on the degree of self-efficacy amongst the teachers. For example, a study on teacher leadership styles and teacher effectiveness levels was conducted by Baharin (2018) whilst Ali et al. (2017) conducted a study on the self-efficacy of physical education teachers in the implementation of teaching physical education subjects. In addition, a study on the professional learning community and the self-efficacy of secondary school teachers was conducted by Ismail, Yen \& Abdullah (2017). Although there were studies on self-efficacy 
amongst students, such as the studies conducted by Adnan \& Ghazali (2011), Sawari et al. (2015) and Sawari et al. (2013), the studies focused on rural students as well as language subjects, such as English, Arabic, and Malay but not science subjects.

Andrew (1998) in Aurah (2017) believed that students' course selections can be explained by self-efficacy. The researcher's opinion was based on a study that identified the factors influencing students' retention and attrition in a nursing course. One of the findings reported that academic self-efficacy was predictive to course withdrawal (Harvey \& McMurray, 1994). Aurah (2017) stated that if the female student has a low self-efficacy to succeed in Science, it can lead to a low achievement and she will tend to avoid the science courses. Nevertheless, female students' participation in science at the university level in Malaysia is higher than for male students. In a study by Tienxhi (2017) on the gender gap in public universities in Malaysia, researchers found that the number of women is higher than the number of male students in seven fields of study, including areas where women have traditionally been less involved, such as math and science.

There were numerous studies reporting a significant relationship between self-efficacy and academic achievement (Nasir \& Iqbal, 2019; Ramnarain \& Ramaila, 2017; Kamalimoghaddam et al., 2016; de Fátima Goulão, 2014). Academic achievement can influence students not only on the choice of academics at the high school level but also on the selection of college and university admissions (Mbathia, 2005). According to Halim \& Meerah (2016), the students' enrollments in science from rural schools in Malaysia were critically low. The factor contributing to the low enrollment might be cause by students' low self-efficacy and achievement in science which lead to their avoidance in science stream at upper secondary and tertiary level. Ardura \& Galán (2019) stated that the research works on the effect of self-efficacy on academic achievement in science at secondary level were scarce. Therefore, considering the issues from the related literature, the purpose of this study is to investigate the relationship between the self-efficacy and achievement of science subjects amongst rural secondary school students in the Rompin district.

\section{Literature Review}

\subsection{Definition of Self-Efficacy}

Self-efficacy is one aspect of the social cognitive theory defined as someone's belief in his or her own ability to achieve a certain level of achievement or performance (Bandura, 1977). In addition, Schunk (1982) defined self-efficacy as a personal judgment towards to what extent their own ability plays in an achievement that may include unpredictable and stressful elements. Perceptions of self-efficacy can influence a person's behaviour in decision making, help assess how much effort and resilience a person puts into a given task and influence an individual's thinking and reaction to emotions (Pajares \& Miller, 1995).

Generally, self-efficacy is divided into two stages, namely high self-efficacy 
and low self-efficacy. Bandura (1997) reported that individuals with high levels of self-efficacy would prefer to perform more challenging tasks. When performing these tasks, individuals with high self-efficacy will put more effort into them than individuals with low self-efficacy. Schunk (1981) further stated that individuals with high levels of self-efficacy will maintain their involvement in a task whilst for individuals with low self-efficacy, they will have less self-efficacy in performing the task.

\subsection{Factors Influencing Self-Efficacy}

Bandura (1977) explained that an individual's self-efficacy can be influenced by four main factors which are performance outcomes, vicarious experiences, verbal persuasion, and physiological condition. The performance factors can affect self-efficacy as they are based on one's experiences or achievements. The experience of success can increase the perception or expectation of mastery, whilst the experience of failure will reduce it. However, if high self-efficacy is shaped by repeated success, the negative response to failure will be diminished and overcome by strong effort and strong self-motivation.

The vicarious experiences factor can influence individual self-efficacy through social modelling. Self-efficacy can be shaped by seeing people in the surroundings, with the same situation, capable of success or mastering skills, such as peers who finished the job well or got good results in the test. By making the people around them as models, they can increase their confidence towards their own abilities to achieve the same success.

Furthermore, individuals who are verbally convinced that they have the ability to master a given activity or task may put greater effort than individuals who have self-doubt and are over-thinking on their self-lacking (Bandura, 1994). With regard to the school environment, verbal persuasion can be explained by the role of teachers in motivating students to learn (Sawari et al., 2015). Through verbal persuasion and guidance from teachers in performing a task, students will be more motivated to perform the task well (Margolis \& McCabe, 2006).

Self-efficacy can also be influenced by the psychological situation and emotional state of an individual. Positive emotional states can enhance one's self-efficacy whilst negative emotions can lower one's self-confidence. According to Sawari et al. (2015), a peaceful school environment can generate positive moods and emotions.

\subsection{Self-Efficacy and Gender}

Studies on the effects of self-efficacy and gender have been conducted by many researchers from various fields of knowledge. The findings that showed significant differences between the level of self-efficacy and gender have been reported in many studies. McKenzie (1999) used the Pearson Correlation test analysis, using the Statistical Package for the Social Sciences (SPSS) software to investigate the correlation between self-efficacy and self-esteem amongst students. The analysis reported that self-efficacy had a significant positive relationship with 
gender. Weisgram \& Bigler (2006) studied the role of self-efficacy in shaping students' interests in science and also reported similar findings when they found that the male students in the control group had higher self-efficacy than the female students. In addition, Aurah (2017) conducted a study on the relationship of self-efficacy beliefs in science, gender, and achievement amongst high school students in Kenya. This study found that there was a significant difference between gender and self-efficacy in science and academic achievements. The results of this study revealed that the female students achieved better achievements than the male students in both science self-efficacy and academic achievement. In addition, this study also emphasised that the findings of the study were not in line with previous research reports which found that the female students often achieved lower achievements than the male students in science-related fields and assignments.

In Malaysia, Mahyuddin et al. (2006) also conducted research that examined the self-efficacy and gender. In their study of the relationship of self-efficacy between students and English achievement, the result showed that there were significant differences in the self-efficacy between girls and boys in English where the females students exhibited higher self-efficacy than the males. In addition, Sawari et al. (2013) also reported that the Pearson Correlation analysis showed that there was a positive and significant relationship between self-efficacy and gender. However, the strength of the relationship was weak $(r=0.361)$. Sawari et al. (2015) reported that there was a significant difference between the self-efficacy of learning and gender. This study found that the female students had higher levels of self-efficacy than the male students. However, the scarcity of published studies on self-efficacy and gender for the science subject in Malaysia has made it difficult for the researcher do a review. Nevertheless, there were some studies relevant to self-efficacy and gender in the science related field found. Students' motivation can be influenced by self-efficacy (Jansen, Scherer, \& Schroeders, 2015; Adnan \& Ghazali, 2011). A comparative study on students' motivation towards science learning in secondary schools in Oman and Malaysia by Salih et al. (2016) reported that there was a significant difference in motivation scores for females $(\mathrm{M}=114.54, \mathrm{SD}=13.14)$ and males $(\mathrm{M}=108.29, \mathrm{SD}=$ 17.87); $\mathrm{t}(3.76), \mathrm{df}=319, p=0.00)$.

Besides that, there are several studies that reported no significant differences between self-efficacy and gender. Amongst them is Kiran \& Sungur (2012) who studied the self-efficacy of middle school science students and their sources in the context of gender. This study reported that there was no significant difference in the self-efficacy of science between the male and female secondary school students. Shkullaku (2013), in his study of the relationship between self-efficacy and academic achievement in the context of gender amongst Albanian students, reported similar findings where there were no differences in the self-efficacy amongst students of different genders. Meanwhile, in Malaysia, a study on the motivation and achievement of Malaysian students in studying Matriculation 
Biology was conducted by Yeoh and Ierardi (2015). The study found that the male students had higher self-efficacy than the females, however there was no significance difference reported. Saleh (2014), in her study on Malaysian students' motivation towards Physics learning, reported a similar finding which was that there were no significant differences found between the male and female students' motivation.

\subsection{Self-Efficacy and Academic Achievement}

Studies on the relationship of self-efficacy and achievement have gained attention from worldwide researchers. Self-efficacy is one of the affective factors often associated with academic achievement (Ramnarain \& Ramaila, 2017). Kamalimoghaddam et al. (2016) conducted a study on the influence of mathematical beliefs on mathematics achievement through mathematical self-efficacy in four schools in Shiraz, Iran. The findings of the study reported that the students who had strong beliefs in mathematics had higher self-efficacy and this led to higher math achievements. A study on the perceptions of academic self-concept and academic self-efficacy in six twice-exceptional (2e) students from a Singapore secondary school was conducted by Wang \& Neihart (2015). This study reported that although $2 \mathrm{e}$ students struggled with some subjects that required memorable understanding and reading skills, they had positive academic self-concept and academic self-efficacy that could influence their academic achievements. In addition, this study also found that the students' self-efficacy of the $2 \mathrm{e}$ was influenced by external factors from parents, teachers, peers, and past achievement. In addition, Caprara et al. (2011) conducted research on the contribution of personality traits and self-efficacy beliefs to academic achievement amongst Italian students. This study reported that openness and self-efficacy at the age of 13 contributed to junior high school achievement. Junior high school achievement contributed to academic self-efficacy at the age of 16 , which indirectly contributed to higher academic achievement. Their findings also showed that academic self-efficacy was a contributing factor to personality traits and academic achievement.

In Malaysia, several studies on self-efficacy and achievement have been conducted. Adnan and Ghazali (2011) conducted a study on students' perceptions of the use of language learning strategies and self-efficacy of university students in peninsular Malaysia. This study reported that there was a significant relationship between language learning strategies and academic achievement. In addition, the study also found that self-efficacy was significantly associated with learning strategies. Yusuf (2011), in his study on the effects of self-efficacy, motivation achievement, and learning strategies on academic achievement, also reported that self-efficacy significantly affected learning achievement. A study by Amin et al. (2016) on predictors of academic achievement in online peer learning amongst undergraduate students in public universities also reported that there was a significant relationship between academic self-efficacy, peer involvement, 
social influence, peer feedback, and cooperation with academic achievement amongst the respondents.

Although there were many studies that reported that there was a significant relationship between self-efficacy and achievement, there were some studies that reported the opposite findings. Baanu et al. (2018) conducted a self-efficacy study and academic achievement of north-central high school chemistry students in Nigeria. The findings showed that no significant relationship existed between the self-efficacy and academic achievement of chemistry students. Ramos-Sánchez and Nichols (2007) studied whether self-efficacy mediated the relationship of generation status and two indicators of academic achievement amongst 192 college students. The findings of this study reported that self-efficacy had no relationship between generation status and academic achievement.

\section{Methodology}

\subsection{Research Design}

This study was a quantitative research using the survey method to study the relationship of science self-efficacy with students' achievement in the science subject. Creswell (2014) stated that quantitative methods are an appropriate approach for explaining the relationships between variables in a research. This method also explains how one variable can influence another variable.

\subsection{Research Population, Sample and Sampling Technique}

In this study, the selected population were Form 4 students taking Science at the National Secondary School located in the rural area of Rompin, Pahang. Rompin was selected as the site of this study because the area is located near the researcher's residential area indirectly providing the researcher with the opportunity to collect the survey data easier. The rationality of choosing Form 4 students as specific research subject for this research is because they already took Form 3 Assessment (PT3) for science subject. PT3 is a national assessment that measuring students' achievement level throughout 10 years of schooling. Therefore, this study intends to see the connection between Form 4 students' self-efficacy and their PT3 achievement in science.

The sampling technique used to obtain the sample for this research is cluster sampling method. This method was selected as sampling technique because it is difficult to identify the exact number of population. In addition, this method is the most time and cost efficient compared to other random sampling method (Alvi, 2016). There are 13 national secondary schools that located at rural area in Rompin. Out of 13 schools, four schools were randomly selected to obtain the final sample for this study. All students in four schools selected are heterogeneous. Therefore, a total of 191 Form 4 students were involved as the sample in this study.

\subsection{Research Instrument}

The instrument used in this study was a questionnaire on student self-efficacy in 
the subject of Science. This questionnaire was constructed based on a study conducted by Lin et al. (2013) based on previous studies, such as Baldwin et al. (1999) and Aydin \& Uzuntiryaki (2009). The items in these instruments were translated into Malay and modifications were made by the researchers to improve the quality of the research results. The questionnaire comprised two sections, section $\mathrm{A}$ and section $\mathrm{B}$.

Section A contained the students' demographic information using the nominal scale and section B contained the questionnaire items related to student self-efficacy in the Science subject using the Likert scale. Students' academic achievement was collected through the information given in section A on their past achievement in PT3. The questionnaire items for section B were divided into five constructs based on the study by Lin et al. (2013) which were conceptual understanding (there were two items, for example: "I know the definition of basic scientific concepts (e.g. gravity, photosynthesis, etc.)"), higher-order cognitive skills (five items, for example: "I can critically evaluate scientific problem solving"), practical work (four items, for example: "I know how to provide experimental equipment in the laboratory"), daily application (six items, for example: "I can explain everyday life using the scientific theory"), and science communication (five items, for example: "In science class, I can express my own ideas clearly"). In addition, the science learning constructs were added in this study to assess the students' confidence in science achievement. This component was important because the self-efficacy of learning can represent the individual's beliefs and expectations about performing the task and achieving a specific outcome (Bandura, 1997).

\subsection{Pilot Test}

A 26-item questionnaire was administered to 90 respondents from three secondary schools in the Rompin district. A pilot study was performed to obtain the reliability of the instrument based on the Alpha Cronbach value. The pilot study found that the item reliability index was 0.89 . Therefore, the questionnaire used was appropriate for use in this study.

\subsection{Data Analyses}

The data from this study were analysed using descriptive and inferential statistics methods. According to Abdullah and Ahmad (2013), a descriptive statistical analysis is used to create, present, and summarise information from the data to facilitate the readers' understanding. The data, analysed and summarised, has been presented in the form of graphs, charts or tables. The descriptive statistical analysis of the study was used to obtain frequency and percentage reports for the demographic findings of the respondents, whilst the mean and standard deviations were obtained from section B's findings, which included six construct of the students' Science self-efficacy.

An inferential statistical analysis was performed to determine the relation- 
ships, differences, and linear relationships between the study variables (Pallant, 2011). The dependent variable in this study was students' academic achievement, whilst the independent variable was self-efficacy in science. The inferential statistical analyses used in this study were two independent sample $t$ tests and the correlation test. The two independent sample $t$ tests were used to test the differences in self-efficacy and academic achievement amongst the students based on gender. Meanwhile, the correlation test was used to identify the relationship between self-efficacy and academic achievement.

\section{Result}

\subsection{Descriptive Analyses}

\section{Demography}

A total of 191 students from 4 schools were involved in this study. Meanwhile, only 187 students were successful in completing the questionnaire. From 187 respondents, $45.5 \%(\mathrm{n}=85)$ were male and $54.5 \%(\mathrm{n}=102)$ were female students (Table 1).

Levels of Students' Science Self-efficacy

The descriptive analyses of the six constructs of science self-efficacy amongst secondary school students in Rompin have been shown in Table 2. The self-efficacy of practical work showed the highest mean scores $(\mathrm{M}=3.77, \mathrm{SD}=0.572)$. Therefore, practical work was the highest construct that contributed to the science self-efficacy of the students compared to conceptual understanding, higher-order cognitive skills, daily application, science communication, and science learning. Whereas, high-order cognitive skills were the lowest construct contributing to the students' science self-efficacy $(\mathrm{M}=3.13, \mathrm{SD}=0.437)$. Overall,

Table 1. Respondent demography.

\begin{tabular}{ccc}
\hline & Frequency (N) & Percentage (\%) \\
\hline Male & 85 & 45.5 \\
Female & 102 & 54.5 \\
Total & 187 & 100 \\
\hline
\end{tabular}

Table 2. Descriptive analyses of the six constructs of science self-efficacy.

\begin{tabular}{cccccc}
\hline & N & Minimum & Maximum & M & SD \\
\hline Conceptual Understanding & 187 & 1.50 & 4.50 & 3.22 & 0.521 \\
Higher-order Cognitive Skills & 187 & 1.50 & 4.17 & 3.13 & 0.437 \\
Practical Work & 187 & 2.00 & 5.00 & 3.77 & 0.572 \\
Daily Application & 187 & 2.33 & 4.67 & 3.43 & 0.528 \\
Science Communication & 187 & 2.00 & 4.75 & 3.45 & 0.521 \\
Science Learning & 187 & 1.75 & 4.75 & 3.39 & 0.496 \\
Science Self-Efficacy & 187 & 2.38 & 4.46 & 3.39 & 0.387 \\
\hline
\end{tabular}


the level of self-efficacy of science amongst the secondary school students in Rompin was high $(\mathrm{M}=3.93, \mathrm{SD}=0.387)$.

Table 3 presents the descriptive statistics for the science self-efficacy based on gender. This study found that the self-efficacy of the female students $(M=3.49$, $\mathrm{SD}=0.363)$ was higher than for the males $(\mathrm{M}=3.28, \mathrm{SD}=0.384)$.

\section{Students' Science Achievement}

Table 4 shows the student achievement levels based on the Form 3 Assessment results (PT3). The study found that the majority of the students obtained an E grade in the Science subject at PT3 with $30.48 \%(\mathrm{n}=57)$ and that was followed by the grade $D$, which was $29.95 \%(n=56)$. Only $3.21 \%(n=6)$ obtained grade $A$ and $2.67 \%(n=5)$ received grade $B$. In addition, there were also students who obtained grade $\mathrm{F}$ with $14.97 \%(\mathrm{n}=28)$.

Table 5 shows the descriptive statistics for student academic achievement by gender. The study found that the academic achievement of the female students $(M=1.83, S D=1.29)$ was higher than that of the men $(M=1.61$, $\mathrm{SD}=1.06)$.

\subsection{Inferential Statistics}

Differences in Science Self-efficacy and Academic Achievement amongst Students of different genders

Two independent sample $\mathrm{t}$-test analyses were used to determine the mean difference in the self-efficacy of science based on gender. Prior to the t-test analysis,

Table 3. Descriptive statistics for science self-efficacy based on gender.

\begin{tabular}{ccccc}
\hline & Gender & N & M & SD \\
\hline \multirow{3}{*}{ Science Self-efficacy } & Male & 85 & 3.28 & 0.384 \\
& Female & 102 & 3.49 & 0.363 \\
\hline
\end{tabular}

Table 4. Students' academic achievements.

\begin{tabular}{ccc}
\hline Science Achievement & No. of Students & Percentage (\%) \\
\hline A & 6 & 3.21 \\
B & 5 & 2.67 \\
C & 35 & 18.72 \\
D & 56 & 29.95 \\
E & 57 & 30.48 \\
F & 28 & 14.97 \\
\hline
\end{tabular}

Table 5. Academic achievement based on gender.

\begin{tabular}{ccccc}
\hline & & $\mathrm{N}$ & $\mathrm{M}$ & $\mathrm{SD}$ \\
\hline \multirow{2}{*}{ Academic achievement } & Male & 85 & 1.61 & 1.06 \\
& Female & 102 & 1.83 & 1.29 \\
\hline
\end{tabular}


normality tests were performed to meet the statistical assumptions for two independent sample $t$ tests. The independent sample $t$-test analysis revealed that there was a significant difference in the self-efficacy of science between male students $(\mathrm{M}=3.28, \mathrm{SD}=0.384)$ and female students $(\mathrm{M}=3.49, \mathrm{SD}=0.363), \mathrm{t}$ $(185)=-3.926 ; p<0.05[95 \% \mathrm{CI}=-0.323$ to -0.107$]$ (Table 6). Whereas, there was no significant difference in academic achievement between the male students $(\mathrm{M}=1.61, \mathrm{SD}=1.059)$ and the female students $(\mathrm{M}=1.83, \mathrm{SD}=1.290), \mathrm{t}$ $(185)=-1.267 ; p>0.05[95 \% \mathrm{CI}=-0.567$ to -0.123$]$.

\section{The relationship between Science self-efficacy and academic achievement}

Based on Table 7, the Pearson correlation coefficient revealed that there was a weak positive relationship between the self-efficacy of science and student academic achievement $(r=0.124)$. The relationship between self-efficacy and academic achievement was not significant at the significance level of 0.05 , where $p=$ 0.09 . Therefore, it can be concluded that there was no significant relationship between science self-efficacy and academic achievement amongst the secondary school students in Rompin.

\section{Discussion}

The purpose of this study was to investigate the science self-efficacy amongst the secondary school students in the Rompin district. Students' science self-efficacy encompassed six constructs, namely conceptual understanding, higher-order cognitive skills, practical work, daily application, science communication, and science learning. The descriptive statistics obtained by the students in this study

Table 6. T-test analysis for self-efficacy of science and academic achievement by gender.

\begin{tabular}{|c|c|c|c|c|c|c|c|c|c|}
\hline & \multirow{2}{*}{ Gender } & \multirow{2}{*}{$\mathbf{N}$} & \multirow{2}{*}{$\mathbf{M}$} & \multirow{2}{*}{ SD } & \multicolumn{3}{|c|}{$\mathrm{t}$ test } & \multicolumn{2}{|c|}{$95 \% \mathrm{CI}$} \\
\hline & & & & & $\mathrm{df}$ & $\mathrm{t}$ & $p$ value & Lower & Upper \\
\hline \multirow{2}{*}{$\begin{array}{c}\text { Science } \\
\text { self-efficacy }\end{array}$} & Male & 85 & 3.28 & 0.384 & \multirow{2}{*}{185} & \multirow{2}{*}{-3.926} & \multirow{2}{*}{0.000} & \multirow{2}{*}{-0.323} & \multirow{2}{*}{-0.107} \\
\hline & Female & 102 & 3.49 & 0.363 & & & & & \\
\hline \multirow{2}{*}{$\begin{array}{c}\text { Academic } \\
\text { achievement }\end{array}$} & Male & 85 & 1.61 & 1.059 & \multirow{2}{*}{185} & \multirow{2}{*}{-1.267} & \multirow{2}{*}{0.207} & \multirow{2}{*}{-0.567} & \multirow{2}{*}{-0.123} \\
\hline & Female & 102 & 1.83 & 1.290 & & & & & \\
\hline
\end{tabular}

Table 7. Pearson Correlation between Science Self-efficacy and Academic Achievement among Secondary School Students in Rompin.

\begin{tabular}{cccc}
\hline & & Academic achievement & Science self-efficacy \\
\hline Academic achievement & Pearson correlation & 1 & 0.124 \\
& Sig. (2-tailed) & & 0.09 \\
& $\mathrm{~N}$ & 187 & 187 \\
Science self-efficacy & Pearson correlation & 0.124 & 1 \\
& Sig. (2-tailed) & 0.09 & 187 \\
\hline
\end{tabular}


were in line with the findings from previous studies that measured similar constructs with this study (Ramnarain \& Ramaila, 2017; Ferrell, Phillips, \& Barbera, 2016). The mean values for all the constructs in the science self-efficacy scale ranged from 3.13 to 3.77 and the overall mean was 3.39. These results demonstrated that the students had positive expectations in their science achievement (Ramnarain \& Ramaila, 2017).

This study found that the students achieved the highest mean scores in the practical work construct, which were practical activities in the science lab. This construct was also categorised as psychomotor skills. The findings of this study were similar to the findings of a study conducted by Ramnarain \& Ramaila (2017), which also measured the dimensions of cognitive skills, psychomotor skills, and daily applications to test the self-efficacy of Chemistry amongst first-year chemistry students at a university in South Africa. However, they found that the students obtained the lowest mean scores in the daily application construct. Meanwhile, the current study was in contrast to their findings, which was that the student's scores were the lowest in the higher-order cognitive skills construct.

The low scores for the higher-order cognitive skills constructs indicated that the students' confidence in their ability to use scientific approaches, such as scientific inquiry skills, problem solving, and critical thinking, was at a low level. A study of higher-order thinking skills in science learning amongst secondary school students was conducted by Saido et al. (2015). The findings also showed that the majority of the students had low levels of cognitive skills. Researchers have suggested two factors causing students' cognitive skills in science learning to be at a low level; they are science curriculum and learning environment. Therefore, to enhance the students' higher-order thinking skills, the science curriculum requires educators to use appropriate teaching and learning methods to enhance student engagement in the learning process (Gillies et al., 2014).

Overall, the national secondary school students in the Rompin area had the lowest level of science self-efficacy to the highest. Based on the findings of the current study, the total mean of the students' science self-efficacy scores ranged from 2.38 to 4.46 . No student had the lowest mean score in the range of $1-1.8$. The majority of the students obtained a moderate level of self-efficacy in science (57\%), with mean scores of 2.7 to 3.4. The total mean of the students' science self-efficacy scores was 3.39. The respondents for this study were from a rural area. Therefore, the findings of this study were in line with Sawari et al. (2015) finding which found that students in rural areas had moderate levels of self-efficacy.

Besides that, this study found that $30.48 \%$ of the students received grade E in the PT3 exam for science subjects. According to the School Exam Analysis System (2016), the grades for E were reaching the minimum. Thus, these findings indicated that the majority of the students had achieved only a minimum level in science subjects and had not mastered the content of the science curriculum as a 
whole. In addition, the study also found that the percentage of the students who achieved the excellence level was very low (3.21\%) and, surprisingly, there were also students who had not reached the minimum level, where $14.97 \%$ of the students had obtained the F grade.

A descriptive analysis of the level of self-efficacy based on gender found that the female students achieved higher levels of self-efficacy in science than the male students. Thus, the findings of this study were in contrast to most previous studies that reported the male students having higher levels of self-efficacy in science than the females (Tenaw, 2013; de Fátima Goulão, 2014; Aslam \& Ali, 2017). However, the findings of this study were in line with the findings of Louis \& Mistele (2011) and Aurah (2017).

Although Louis \& Mistele (2011) presented similar descriptive findings but statistically, the findings revealed that there was no significant difference in the level of science self-efficacy between the male students and the female students. These findings were contrary to the current study where two independent sample t-test analyses indicated that there were significant differences in the level of science self-efficacy between the male and female students. As such, these findings were seen to have particular implications, especially for science teachers. Science teachers need to be aware of the differences in the self-efficacy of learning between their male and female students whilst designing a restructuring curriculum that has been implemented with a more appropriate approach (Aurah, 2017). Involving students in inquiry-based science whilst in high school can contribute to the mastery of the skills needed to enhance the strong self-efficacy of science (Britner \& Pajares, 2006).

Furthermore, a descriptive analysis of academic achievement by gender indicated that the female students had higher academic achievement compared to the male students. However, no statistically significant differences were reported in this study. The findings of this study were parallel with the findings of Louis \& Mistele (2011) and Shkullaku (2013) who reported no significant differences between academic achievement and gender. Meanwhile, Oluwatelure (2015), in her study of "Gender Differences in the Attitudes of Public Secondary Students in Science", reported different findings. She found that there was a significant difference between achievement and gender.

The Pearson correlation was conducted to identify the relationship between student self-efficacy and academic achievement amongst the secondary school students in Rompin. This study found that there was no significant relationship between science self-efficacy and academic achievement. Therefore, this finding failed to reject the hypothesis used in the study. This study's findings were in contrast to the findings of previous studies which reported a significant relationship between self-efficacy and academic achievement (e.g. Witt-Rose, 2003; Britner \& Pajares, 2006; Wang \& Neihart, 2015; Kamalimoghaddam et al., 2016). Nevertheless, the findings in this study were in line with the study conducted by Baanu et al. (2018); Sahranavard \& Hassan (2012); Zanariah (2010); and Ra- 
mos-Sánchez \& Nichols (2007). The failure of this study to prove a significant relationship between science self-efficacy and academic achievement may be due to the use of non-specific self-efficacy measures and the measures used to measure the achievement levels (Pajares, 1996). Although the findings of this study did not show any significant correlation between self-efficacy and academic achievement, self-efficacy is still believed as a potential variable that influences student achievement if considering long-term outcomes (Ramos-Sánchez \& Nichols, 2007) Besides that, Baanu et al. (2018) findings suggested that academic achievement may not be influenced by the students' self-efficacy levels if other factors that were much more crucial, were disregarded. Students' science self-efficacy can be influenced by many factors. The most crucial variables influencing self-efficacy are those related to education, families, society, and development (Schunk \& DiBenedetto, 2016).

\section{Conclusion, Implication and Future Research}

In conclusion, this study examined the levels of science self-efficacy and academic achievement and the differences in the levels of self-efficacy of science between male and female students, and it identified the relationship of the students' science self-efficacy with their academic achievement. The mean number of the students' self-efficacy scores was found to be moderate at 3.39 whilst the students' academic achievement levels only reached the minimum grade $\mathrm{E}$ in the PT3 examination. In addition, this study found that there were significant differences in the levels of science self-efficacy between the male and female students. Therefore, this study rejected the first null hypothesis that there was no significant difference in the degree of self-efficacy between male and female students, whereas, the findings reported that there was no significant difference in the academic achievement of the students based on gender. In addition, this study failed to reject the second null hypothesis of the study since there was no significant relationship between self-efficacy and academic achievement, where $\mathrm{r}$ $=0.124$ and $p=0.09$.

Based on the findings obtained in this study, there are several significant implications that can assist the Ministry of Education Malaysia (MOE), schools, and teachers, especially science education teachers, in developing strategies to enhance student science self-efficacy and thus, increase students' participation in Science streams. Firstly, there is necessity for science teacher to consider the gender differences of science self-efficacy in choosing appropriate instructional design. Secondly, teachers should engage student with creative learning strategies that include various dimensions of self-efficacy (e.g. higher-order cognitive skills, communication skills, conceptual understanding, etc.). Next, considering the critically low of students' achievement in PT3, this study supports the idea that students' enrollment in science stream is influenced by previous achievement. According to Bandura (1977), previous achievement can influence someone's self-efficacy which lead to their future decision making. In addition, the 
selection system of students' admission in science stream at upper secondary level in Malaysia is depending on their PT3 performance.

In order to obtain more accurate findings, replication in carrying out this study is recommended. In order to improve the research findings, the factors or constructs that measure student self-efficacy should be more specific and appropriate for measuring student academic achievement. In addition, replication of the study is recommended to make use of a larger study sample. Since the self-efficacy of cognitive skills had the lowest impact in this study, further studies on cognitive skills are also recommended to identify the cause. Based on the findings of the study which showed that the achievement of science amongst the students was only to a minimum, further study to determine the factors or causes of this situation is strongly encouraged.

\section{Acknowledgements}

Acknowledgement to grant GG-2019-048.

\section{Conflicts of Interest}

The authors declare no conflicts of interest regarding the publication of this paper.

\section{References}

Abdullah, M. L., \& Ahmad, W. M. A. W. (2013). Analisis Data Dengan Statistik Asas. Kuala Terengganu: Penerbit UMT.

Abu-Tineh, A. M., Khasawneh, S. A., \& Khalaileh, H. A. (2011). Teacher Self-Efficacy and Classroom Management Styles in Jordanian Schools. Management in Education, 25, 175-181. https://doi.org/10.1177/0892020611420597

Adnan, M. A. M., \& Ghazali, Z. (2011). Persepsi Pelajar Terhadap Penggunaan Strategi Pembelajaran Bahasa dan Efikasi Kendiri: Kajian Ke Atas Pelajar Universiti di Semenanjung Malaysia. Sarjana Journal, 26, 81-99.

Ali, S. K. S., Hassan, M. Z. C., \& Jani, J. (2017). Efikasi kendiri guru pendidikan jasmani terhadap pelaksanaan pengajaran mata pelajaran pendidikan jasmani. JuKu: Jurnal Kurikulum \& Pengajaran Asia Pasifik, 2, 43-51.

Alvi, M. (2016). A Manual for Selecting Sampling Techniques in Research.

Amin, I. M. H., Hassan, N. C., \& Jalil, H. A. (2016). Predictors of Academic Achievements in Online Peer Learning among Undergraduate Students in a Malaysian Public University.

Andrew, S. (1998). Self-Efficacy as a Predictor of Academic Performance in Science. Journal of Advanced Nursing, 27, 596-603. https://doi.org/10.1046/j.1365-2648.1998.00550.x

Ardura, D., \& Galán, A. (2019). The Interplay of Learning Approaches and Self-Efficacy in Secondary School Students' Academic Achievement in Science. International Journal of Science Education, 41, 1723-1743. https://doi.org/10.1080/09500693.2019.1638981

Aslam, S., \& Ali, M. S. (2017). Effect of Self-Efficacy on Students' Achievement in Science: A Case of Secondary School Students in Pakistan. European Journal of Education Stu- 
dies, 3, 220-235.

Aurah, C. (2017). Investigating the Relationship between Science Self-Efficacy Beliefs, Gender, and Academic Achievement, among High School Students in Kenya.

Aydin, Y. Ç., \& Uzuntiryaki, E. (2009). Development and Psychometric Evaluation of the High School Chemistry Self-Efficacy Scale. Educational and Psychological Measurement, 69, 868-880. https://doi.org/10.1177/0013164409332213

Baanu, T. F., Oyelekan, O. S., \& Olorundare, A. S. (2018). Self-Efficacy and Chemistry Students' Academic Achievement in Senior Secondary Schools in North-Central, Nigeria. MOJES: Malaysian Online Journal of Educational Sciences, 4, 43-52.

Baharin, B., Adnan, M. H., Zin, M. H. M., Kamaludin, M. N., \& Mansor, A. N. (2018). Gaya Kepimpinan Guru Besar Dan Tahap Efikasi Guru. Journal of Personalized Learning, 2, 9-17.

Baker, D. (2013). What works: Using Curriculum and Pedagogy to Increase Girls' Interest and Participation in Science. Theory into Practice, 52, 14-20.

https://doi.org/10.1080/07351690.2013.743760

Baldwin, J. A., Ebert-May, D., \& Burns, D. J. (1999). The Development of a College Biology Self-Efficacy Instrument for Nonmajors. Science Education, 83, 397-408.

Bandura, A. (1977). Self-Efficacy: Toward a Unifying Theory of Behavioral Change. Psychological Review, 84, 191.

Bandura, A. (1994). Self-Efficacy. In V. S. Ramachaudran (Ed.), Encyclopedia of Human Behavior (Vol. 4, pp. 71-81). New York: Academic Press.

Britner, S. L., \& Pajares, F. (2006). Sources of Science Self-Efficacy Beliefs of Middle School Students. Journal of Research in Science Teaching: The Official Journal of the National Association for Research in Science Teaching, 43, 485-499. https://doi.org/10.1002/tea.20131

Caprara, G. V., Vecchione, M., Alessandri, G., Gerbino, M., \& Barbaranelli, C. (2011). The Contribution of Personality Traits and Self-Efficacy Beliefs to Academic Achievement: A Longitudinal Study. British Journal of Educational Psychology, 81, 78-96. https://doi.org/10.1348/2044-8279.002004

Creswell, J. W. (2014). Educational Research: Planning, Conducting and Evaluating Quantitative and Qualitative Research (4th ed.). Upper Saddle River, NJ: Pearson.

Da Wan, C., Sirat, M., \& Razak, D. A. (2018). Education in Malaysia towards a Developed Nation.

de Fátima Goulão, M. (2014). The Relationship between Self-Efficacy and Academic Achievement in Adults' Learners. Athens Journal of Education, 1, 237-246.

https://doi.org/10.30958/aje.1-3-4

Ferrell, B., Phillips, M. M., \& Barbera, J. (2016). Connecting Achievement Motivation to Performance in General Chemistry. Chemistry Education Research and Practice, 17, 1054-1066. https://doi.org/10.1039/C6RP00148C

Gillies, R. M., Nichols, K., Burgh, G., \& Haynes, M. (2014). Primary Students' Scientific Reasoning and Discourse during Cooperative Inquiry-Based Science Activities. International Journal of Educational Research, 63, 127-140.

https://doi.org/10.1016/j.ijer.2013.01.001

Halim, L., \& Meerah, T. S. M. (2016). Science Education Research and Practice in Malaysia. In Science Education Research and Practice in Asia (pp. 71-93). Singapore: Springer. https://doi.org/10.1007/978-981-10-0847-4_5

Harvey, V., \& McMurray, N. (1994). Self-Efficacy: A Means of Identifying Problems in 
Nursing Education and Career Progress. International Journal of Nursing Studies, 31, 471-485. https://doi.org/10.1016/0020-7489(94)90017-5

Henriksen, E. K., Dillon, J., \& Ryder, J. (2015). Understanding Student Participation and Choice in Science and Technology Education. Dordrecht, the Netherlands: Springer. https://doi.org/10.1007/978-94-007-7793-4

Ismail, A., Yen, L. H., \& Abdullah, A. G. K. (2017). Komuniti pembelajaran profesional dan efikasi kendiri guru sekolah menengah di Pulau Pinang. JuPiDi: Jurnal Kepimpinan Pendidikan, 2, 1-12.

Jansen, M., Scherer, R., \& Schroeders, U. (2015). Students' Self-Concept and Self-Efficacy in the Sciences: Differential Relations to Antecedents and Educational Outcomes. Contemporary Educational Psychology, 41, 13-24.

https://doi.org/10.1016/j.cedpsych.2014.11.002

Kamalimoghaddam, H., Tarmizi, R. A., Ayub, A. F. M., \& Jaafar, W. M. W. (2016). The Influences of Mathematics Beliefs on Mathematics Achievement through Mathematics Self-Efficacy: A Structural Equation Model. Communication in Mathematical Modeling and Applications, 1, 44-51.

Kiran, D., \& Sungur, S. (2012). Middle School Students' Science Self-Efficacy and Its Sources: Examination of Gender Difference. Journal of Science Education and Technology, 21, 619-630. https://doi.org/10.1007/s10956-011-9351-y

Lin, T. J., Tan, A. L., \& Tsai, C. C. (2013). A Cross-Cultural Comparison of Singaporean and Taiwanese Eighth Graders' Science Learning Self-Efficacy from a Multi-Dimensional Perspective. International Journal of Science Education, 35, 1083-1109. https://doi.org/10.1080/09500693.2013.776193

Louis, R. A., \& Mistele, J. M. (2011). The Differences in Scores and Self-Efficacy by Student Gender in Mathematics and Science. International Journal of Science and Mathematics Education, 10, 1163-1190. https://doi.org/10.1007/s10763-011-9325-9

Lyons, T., \& Quinn, F. (2010). Choosing Science: Understanding the Declines in Senior High School Science Enrolments.

Mahyuddin, R., Elias, H., Cheong, L. S., Muhamad, M. F., Noordin, N., \& Abdullah, M. C. (2006). The Relationship between Students' Self-Efficacy and Their English Language Achievement. Malaysian Journal of Educators and Education, 21, 61-71.

Margolis, H., \& McCabe, P. P. (2006). Improving Self-Efficacy and Motivation: What to Do, What to Say. Intervention in School and Clinic, 41, 218-227. https://doi.org/10.1177/10534512060410040401

Mbathia, M. (2005). Cream for Law and Medicine. The Standard. Nairobi: The Standard Ltd.

McDonald, C. V. (2016). STEM Education: A Review of the Contribution of the Disciplines of Science, Technology, Engineering and Mathematics. Science Education International, 27, 530-569

McKenzie, J. K. (1999). Correlation between Self-Efficacy and Self-Esteem in Students.

Ministry of Science, Technology and Innovation (MOSTI) (2016). National Science, Technology, and Innovation Policy.

https://mastic.mestecc.gov.my/sites/default/files/sti-policies/1544414905/dasar_sti_neg ara_-_2016.pdf

Nasir, M., \& Iqbal, S. (2019). Academic Self Efficacy as a Predictor of Academic Achievement of Students in Pre Service Teacher Training Programs. Bulletin of Education and Research, 41, 33.

Nazirah, M. S., Talib, O., \& Norishah, T. P. (2013). Merging of Game Principles and 
Learning Strategy Using Apps for Science Subjects to Enhance Student Interest and Understanding. Sains Humanika, 63, 1-6. https://doi.org/10.11113/jt.v63.1998

Oluwatelure, T. A. (2015). Gender Difference in Achievement and Attitude of Public Secondary School Students towards Science. Journal of Education and Practice, 6, 87-92.

Pajares, F. (1996). Self-Efficacy Beliefs in Academic Settings. Review of Educational Research, 66, 543-578. https://doi.org/10.3102/00346543066004543

Pajares, F., \& Miller, M. D. (1995). Mathematics Self-Efficacy and Mathematics Performances: The Need for Specificity of Assessment. Journal of Counseling Psychology, 42, 190-198. https://doi.org/10.1037/0022-0167.42.2.190

Pallant, J. (2011). Survival Manual. A Step by Step Guide to Data Analysis Using SPSS.

Phang, F. A., Abu, M. S., Ali, M. B., \& Salleh, S. (2014). Faktor penyumbang kepada kemerosotan penyertaan pelajar dalam aliran sains: Satu analisis sorotan tesis. Sains $\mathrm{Hu}$ manika, 2, 1-17.

Ramnarain, U., \& Ramaila, S. (2017). The Relationship between Chemistry Self-Efficacy of South African First Year University Students and Their Academic Performance. Chemistry Education Research and Practice, 19, 60-67. https://doi.org/10.1039/C7RP00110J

Ramos-Sánchez, L., \& Nichols, L. (2007). Self-Efficacy of First-Generation and Non-First-Generation College Students: The Relationship with Academic Performance and College Adjustment. Journal of College Counseling, 10, 6-18. https://doi.org/10.1002/j.2161-1882.2007.tb00002.x

Sahranavard, M., \& Hassan, S. A. (2012). The Relationship Between self-Concept, Self-Efficacy, Self-Esteem, Anxiety and Science Performance among Iranian Students. Middle-East Journal of Scientific Research, 12, 1190-1196.

Saido, G. M., Siraj, S., Nordin, A. B. B., \& Al-Amedy, O. S. (2015). Higher Order Thinking Skills among Secondary School Students in Science Learning. MOJES: Malaysian Online Journal of Educational Sciences, 3, 13-20.

Saleh, S. (2014). Malaysian Students' Motivation towards Physics Learning. European Journal of Science and Mathematics Education, 2, 223-232.

Salih, M., Mai, M. Y., \& Al Shibli, A. (2016). Students' Motivation toward Science Learning in Secondary Schools in Oman and Malaysia: A Comparative Study. Journal of Research, Policy \& Practice of Teachers \& Teacher Education (JRPPTTE), 6, 16-24.

Sawari, S. S. B. M., Kazeem, B., \& Mansor, N. B. (2013). Investigating the Correlationship between Level of Self-Efficacy and Gender.

Sawari, S. S. M., Ghazali, M. A. I., \& Mansor, N. (2015). A Study of Learning Efficacy among Rural Area Students in Ledang Johor. Sains Humanika, 5, 1-9.

Schunk, D. H. (1981). Modeling and Attributional Effects on Children's Achievement: A Self-Efficacy Analysis. Journal of Educational Psychology, 73, 93-105.

https://doi.org/10.1037/0022-0663.73.1.93

Schunk, D. H. (1982). Effects of Effort Attributional Feedback on Children's Perceived Self-Efficacy and Achievement. Journal of Educational Psychology, 74, 548-556. https://doi.org/10.1037/0022-0663.74.4.548

Schunk, D. H., \& DiBenedetto, M. K. (2016). Self-Efficacy Theory in Education. Handbook of Motivation at School, 2, 34-54.

Shkullaku, R. (2013). The Relationship between Self-Efficacy and Academic Performance in the Context of Gender among Albanian Students. European Academic Research, 1, 
467-478

Tenaw, Y. A. (2013). Relationship between Self-Efficacy, Academic Achievement and Gender in Analytical Chemistry at Debre Markos College of Teacher Education. African Journal of Chemical Education, 3, 3-28.

Tienxhi, J. Y. (2017). The Gender Gap in Malaysian Public Universities: Examining the 'Lost Boys'. Journal of International and Comparative Education (JICE), 6, 1-16. https://doi.org/10.14425/JICE.2017.6.1.0116

US Department of Commerce (2011). NOAA: Cultivating the Next Generation of STEM Workers, One Student at a Time.

https://legacy2.noaacrest.org/news-and-events/detail/noaa-cultivating-the-next-generat ion-of-stem-workers-one-student-at-a-time

Wang, C. W., \& Neihart, M. (2015). Academic Self-Concept and Academic Self-Efficacy: Self-Beliefs Enable Academic Achievement of Twice-Exceptional Students. Roeper Review, 37, 63-73. https://doi.org/10.1080/02783193.2015.1008660

Weisgram, E. S., \& Bigler, R. S. (2006). Girls and Science Careers: The Role of Altruistic Values and Attitudes about Scientific Tasks. Journal of Applied Developmental Psychology, 27, 326-348. https://doi.org/10.1016/j.appdev.2006.04.004

Wilson, R., \& Mack, J. (2014). Declines in High School Mathematics and Science Participation: Evidence of Students' and Future Teachers' Disengagement with Maths. International Journal of Innovation in Science and Mathematics Education, 22, 35-48.

Witt-Rose, D. L. (2003). Student Self-Efficacy in College Science: An Investigation of Gender, Age, and Academic Achievement.

Yee, A. L. S., \& Fah, L. Y. (2014). Sikap dan Kebimbangan Kimia Dalam Kalangan Pelajar Aliran Sains: Satu Pendekatan Pemodelan Persamaan Struktural (SEM). Journal for Educational Thinkers, 5, 99-117.

Yeoh, M. P., \& Ierardi, E. (2015). Motivation and Achievement of Malaysian Students in Studying Matriculation Biology. International Journal of Advanced Research, 3, 966-978.

Yusuf, M. (2011). The Impact of Self-Efficacy, Achievement Motivation, and Self-Regulated Learning Strategies on Students' Academic Achievement. Procedia-Social and Behavioral Sciences, 15, 2623-2626. https://doi.org/10.1016/j.sbspro.2011.04.158

Zanariah, S. (2010). Hubungan antara sikap dan efikasi kendiri Sains pelajar bumiputera dan bukan bumiputera dengan pencapaian Sains di daerah Lahad Datu, Sabah. Doctoral Dissertation, Kedah, Malaysia: Universiti Utara Malaysia. 